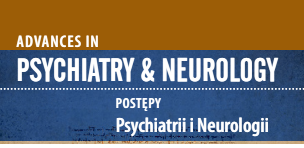

Correspondence to/

Adres do korespondencji:

Magdalena Golędzinowska

Specjalistyczna Poradnia

Psychologiczno-Pedagogiczna TOP

ul. Raszyńska 8/10

02-026 Warszawa, Polska

e-mail:

goledzinowska.magdalena@gmail.com

Submitted/Otrzymano: 08.07.2017

Accepted/Przyjęto do druku: 18.12.2017

\section{WORRYING IN PEOPLE WITH SCHIZOPHRENIA} MARTWIENIE SIĘ OSÓB CHORUJĄCYCH
NA SCHIZOFRENIĘ

\author{
Magdalena Golędzinowska', Maryla Sawicka², \\ Agnieszka Żochowska ${ }^{3}$
}

\author{
'Specialist Psychological-Pedagogical Clinic TOP, Warsaw, Poland \\ ${ }^{2}$ The Maria Grzegorzewska Pedagogical University, Warsaw, Poland \\ 3Jan Mazurkiewicz Mazovian Specialist Health Center, Pruszków, Poland
}

'Specjalistyczna Poradnia Psychologiczno-Pedagogiczna TOP, Warszawa, Polska ${ }^{2}$ Akademia Pedagogiki Specjalnej im. Marii Grzegorzewskiej, Warszawa, Polska ${ }^{3}$ Mazowieckie Specjalistyczne Centrum Zdrowia im. Jana Mazurkiewicza,

Pruszków, Polska

\begin{abstract}
Introduction: Worrying is a cognitive process observed both in healthy people and those who suffer from mental disorders. The analyses of its relevance to coping with difficult situations can be found in the literature but there is little information on its significance and extent in the lives of people who suffer from schizophrenia.

Purpose: The aim of the study was to define the prevalence of worrying and its relationship to the social functioning of people suffering from schizophrenia, compared to the worrying experienced by healthy subjects.

Methods: The study involved 37 patients with a diagnosis of schizophrenia (ICD-10), currently hospitalized in rehabilitation day wards, and 38 healthy subjects. The following research tools were used: the Penn State Worry Questionnaire (PSWQ), the Social Functioning Questionnaire, and the Global Assessment of Functioning and Socio-demographic Background Questionnaire. The control group comprised healthy subjects matched for age and sex with the clinical group of patients with schizophrenia.

Results: The degree of worrying exhibited by people with schizophrenia differed from that obtained in the analysis of healthy subjects. The difference occurred at the level of statistical tendency. The worrying experienced by people in the clinical group was related to various areas of functioning: social functioning, communication, building interpersonal relationships or effective ways of spending leisure time.

Conclusions: Our results show a statistical tendency towards people with schizophrenia worrying more often than people in the control group. A significant and negative covariance was noted in the clinical group between the tendency to worry, communication skills and building interpersonal relationships as well as effective leisure time management.
\end{abstract}

Key words: worrying, social functioning, schizophrenia.

\title{
Streszczenie
}

Wstęp: Martwienie się jest procesem poznawczym obserwowanym zarówno u osób zdrowych, jak u osób z zaburzeniami psychicznymi. W literaturze przedmiotu podkreśla się jego znaczenie w procesie radzenia sobie z sytuacjami trudnymi. Niewiele jest informacji o znaczeniu i rozmiarze tego zjawiska w życiu osób chorych na schizofrenię.

Cel: Celem badania była próba określenia rozmiaru zjawiska martwienia się i jego związków z funkcjonowaniem społecznym osób chorych na schizofrenię, w porównaniu z martwieniem się osób zdrowych.

Metody: W badaniu wzięło udział 37 pacjentów, aktualnie hospitalizowanych w oddziałach dziennych rehabilitacyjnych, z rozpoznaną schizofrenią (ICD-10) oraz 38 osób zdrowych. Zastosowano następujące narzędzia badawcze: Kwestionariusz Oceny Martwienia się (Penn State Worry Questionnaire - PSWQ), Skalę Funkcjonowania Społecznego (Global Assessment of Functioning GAF), Kwestionariusz Danych Społeczno-Demograficznych. Osoby zdrowe stanowiły grupę kontrolną, zbliżoną wiekiem oraz podziałem ze względu na płeć do składu grupy klinicznej - chorych na schizofrenię.

Wyniki: Wyniki osób chorych na schizofrenię różnią się od wyników osób zdrowych pod względem poziomu martwienia się i różnica ta występuje na poziomie tendencji statystycznej. Poziom martwienia się osób z grupy klinicznej wiązał się z obszarami takimi jak: funkcjonowanie społeczne, komunikowanie się, budowanie więzi interpersonalnych, zagospodarowywanie czasu wolnego. 
Wnioski: Otrzymane wyniki wskazują, że istnieje tendencja statystyczna wskazująca na to, że osoby chore na schizofrenię martwią się częściej niż osoby z grupy kontrolnej. W grupie klinicznej odnotowano istotną i ujemną współzmienność występującą pomiędzy skłonnością do martwienia się a umiejętnościami komunikacyjnymi i budowaniem więzi międzyludzkich oraz efektywnym zarządzaniem czasem wolnym.

Słowa kluczowe: martwienie się, funkcjonowanie społeczne, schizofrenia.

\section{INTRODUCTION}

Worrying is a negative and intrusive cognitive habit, which can occur as a cognitive component of anxiety but can also be caused by anxious thoughts or various events in the individual's life and environment. Processing Efficiency Theory treats worrying as an element of anxiety that affects cognitive performance [1]. Worrying is a process related to the activity of the frontal lobes and anterior cingulate cortex $[2,3]$.

The relationship between worrying and social functioning has not yet been clearly assessed. On the one hand, worrying involves a number of cognitive processes characterized by negative consequences for an individual's life, such as unproductivity and limited ability to learn based on experience, which is associated with the tendency to repeat non-adaptive behaviours, chronicity, excessive focus in anticipation of the appearance unfortunate events [4]. Yet on the other hand, worrying can help in avoiding negative events and also help a person prepare for the worst or unavoidable circumstances $[5,6]$. Low-intensity worrying may play an adaptive and motivating role [7]. The beneficial effects of worrying can also be understood as a subjectively perceived reduced likelihood of an undesirable event occurring in the future $[5,8]$. Research has demonstrated that pathological and adaptive worrying are a kind of continuum. Pathological worrying is perceived as disturbing, uncontrollable, intrusive and undesirable while adaptive worrying can facilitate decision-making without hindering activity [9].

Research has also shown that worrying is linked with such mental disorders as depression [10], insomnia [11], obsessive-compulsive disorder [12], eating disorders [13] and anxiety disorders [14].

Worrying has rarely been discussed in relation to the clinical group of people with schizophrenia, which is why this study's objective was to analyse the relationship that the worrying process might have with the different areas of social functioning of this group of patients.

Based on the literature available, the following research questions were posed:

1. Can worrying affect the functioning of people with chronic schizophrenia?

\section{WSTĘP}

Martwienie się jest intruzywnym, poznawczym nawykiem o zabarwieniu negatywnym. Nawyk ten może stanowić poznawczą komponentę lęku, spowodowaną lękowymi myślami lub wydarzeniami w środowisku. Teoria efektywności przetwarzania informacji traktuje martwienie się jako element stanu lęku wpływający na wydajność poznawczą [1]. Martwienie się jest procesem związanym $\mathrm{z}$ aktywnością kory płatów czołowych i przedniej części kory zakrętu obręczy [2, 3].

Związek martwienia się z funkcjonowaniem społecznym nie jest jednoznacznie oceniany. $Z$ jednej strony, martwienie się angażuje szereg procesów poznawczych charakteryzujących się negatywnymi konsekwencjami w życiu, takimi jak bezproduktywność i ograniczona zdolność do uczenia się w oparciu o własne doświadczenia, co wiąże się z tendencją do powtarzania nieadaptacyjnych zachowań, przewlekłością trwania, nadmiernym skupieniem się w oczekiwaniu na pojawienie się niepomyślnych wydarzeń [4]. Z drugiej strony, poprzez martwienie się można uniknąć negatywnych zdarzeń oraz może ono pomóc w przygotowaniu się na to, co najgorsze i nieuniknione $[5,6]$. Martwienie się o niskim nasileniu może spełniać funkcję adaptacyjną oraz stanowić motywację do działania [7]. Korzystne działanie martwienia się może być dostrzegane w subiektywnie odbieranym redukowaniu prawdopodobieństwa pojawienia się niepożądanego wydarzenia w przyszłości $[5,8]$. Badania ujawniły, że martwienie się patologiczne i adaptacyjne stanowią swoiste kontinuum. Martwienie się patologiczne jest postrzegane jako niepokojące, niekontrolowane, natrętne i niechciane. Jednocześnie adaptacyjne martwienie się jest przyjemniejsze, ułatwia podejmowanie decyzji i nie przeszkadza w działaniu [9].

Badania wykazały, że martwienie się jest związane z takimi zaburzeniami psychicznymi jak: depresja [10], bezsenność [11], zaburzenia obsesyjno-kompulsyjne [12], zaburzenia odżywiania [13], zaburzenia lękowe [14].

Martwienie się rzadko jest opisywane w grupie klinicznej, jaką są osoby chore na schizofrenię. Dlatego też celem niniejszego badania była analiza związków, jakie może mieć proces martwienia się w różnych obszarach funkcjonowania społecznego osób chorych na schizofrenię.

Na podstawie dostępnej literatury postawiono następujące pytania badawcze:

1. Czy martwienie się ma związek z funkcjonowaniem osób chorych na przewlekłą schizofrenię? 
2. Are there any differences between the severity of worrying experienced by people with schizophrenia and by healthy people?

\section{METHODS}

The study of patients with schizophrenia took place in the daytime psychiatric rehabilitation wards operating in the Mokotów district of Warsaw. All subjects were diagnosed with schizophrenia according to ICD-10. The study excluded people who gave no consent, actively abused alcohol or other psychoactive substances and those with a suspected dementia syndrome. All patients were stable as assessed at the qualifying examination during the admission to the ward, which required symptomatic remission sufficient to enable patients' participation in intensive rehabilitation and therapy. The type of medication the patients took and its dosage had to remain unchanged for at least two weeks prior to the study. The patients received second generation antipsychotics such as amisulpride, aripiprazole, risperidone, olanzapine, quetiapine and the first generation drugs Clopixol and perazine.

Each patient was examined by a single run of tests, which included:

- Birchwood's Social Functioning Scale (SFS) Part B modified for the purposes of the study. Altogether eight scales were developed with the first six being unchanged but the seventh being split into two scales, number VII referring to work, asking whether patients had a job, had worked recently or were unemployed, and scale VIII referring to patients' subjective assessment of their ability to work, capacity to work, and frequency of their finding a job. For the purposes of the study, scales VII and VIII were treated as qualitative. We needed to find out whether our patients had a job or felt capable of working [15].

- The Penn State Worry Questionnaire (PSWQ) by Meyer, Miller and Borkovec (1990), adapted by Janowski [16]. The tool consists in 16 items. Subjects are asked to give an answer on a 5-step scale assessing the extent to which a statement is typical for them. 5 points are given for the answer "very typical of me" and 1 point for "not at all typical of me". The total score is a sum of all points, with the maximum score for the highest severity of worrying being 80 points. Scores at the level of 44-62 points are assessed as average, and above 63 points as high. The questionnaire is a commonly used tool considered to have very good psychometric properties $(\alpha$-Cronbach coefficient $=0.80)[9,17,18]$. It is used with various clinical groups, including people with schizophrenia [19].

- The Global Assessment of Functioning (GAF) evaluates the overall functioning of subjects in three
2. Czy występują różnice pomiędzy nasileniem martwienia się osób chorych na schizofrenię i osób zdrowych?

\section{METODY}

Badanie osób chorujących na schizofrenię odbyło się w oddziałach dziennych rehabilitacji psychiatrycznej funkcjonujących na terenie Warszawy w dzielnicy Mokotów. U wszystkich badanych rozpoznano schizofrenię zgodnie ze wskazaniami ICD-10. Z badania wykluczono osoby, które nie wyrazily na nie zgody, aktywnie nadużywały alkoholu lub innych substancji psychoaktywnych oraz osoby z podejrzeniem zespołu otępiennego. Byli to pacjenci $\mathrm{w}$ stabilnym stanie psychicznym ocenianym podczas kwalifikacji do oddziałów, gdzie wymogiem jest pomyślna remisja objawowa umożliwiająca udział $\mathrm{w}$ intensywnych zajęciach rehabilitacyjno-terapeutycznych. Rodzaj przyjmowanego leku i jego dawka pozostawały niezmienione przez co najmniej dwa tygodnie przed badaniem. Pacjenci przyjmowali leki przeciwpsychotyczne II generacji: amisulprid, aripiprazol, risperidon, olanzapinę, kwetiapinę, oraz I generacji: Clopixol, perazynę.

Każdy pacjent był badany jednorazowo zestawem testów, który zawierał:

- Skalę Funkcjonowania Społecznego cz. B (SFS) autorstwa Birchwooda. Skala Funkcjonowania Społecznego cz. B została zmodyfikowana na potrzeby badania. W sumie powstało osiem skal, gdzie sześć pierwszych zostało bez zmian, zaś z siódmej skali wyodrębniono dwie: VII. Praca czy osoba ma pracę, posiadała ją niedawno lub nie pracuje wcale oraz VIII. Subiektywna ocena dotycząca podjęcia pracy - subiektywna ocena osoby badanej dotycząca jej zdolności do wykonywania pracy, częstotliwość szukania pracy. Ze względu na potrzeby badania skale VII i VIII rozpatrywano jakościowo. Sprawdzano, czy osoba ma pracę i czy czuje się zdolna do jej podjęcia [15].

- Kwestionariusz Oceny Martwienia się (PSWQ) autorstwa Meyer, Miller, Borkovec (1990) w adaptacji Janowskiego [16]. Narzędzie to składa się z 16 pozycji testowych, gdzie na 5-stopniowej skali badani oceniają, na ile dane stwierdzenie jest dla nich typowe. Punkty przyznawane są na podstawie odpowiedzi, gdzie "bardzo typowe dla mnie” to 5 punków, a „w ogóle nietypowe dla mnie" - 1 punkt. Wynik ogólny stanowi suma wszystkich punktów uzyskanych z poszczególnych odpowiedzi, gdzie maksymalny wynik i jednocześnie najwyższe nasilenie skłonności do martwienia się wynosi 80 . Otrzymane wyniki na poziomie 44-62 punktów oceniane są jako średnie, a te uzyskane powyżej 63 punktów traktowane są jako będące na poziomie wysokim. Kwestionariusz jest powszechnie używanym narzędziem, które posiada bardzo dobre właściwości psychometryczne (współczynnik a Cronbacha $=0,80$ ) $[9,17,18]$. Jest to narzędzie stosowane także w grupach klinicznych, w tym u osób chorych na schizofrenię [19]. 
areas: psychopathology, social functioning and professional functioning. The scale consists in 10 steps from the lowest to the highest degree. 0 stands for very bad functioning and 100 for very good functioning [20].

- The Socio-demographic Data Questionnaire was developed for the purposes of the study and asked questions about a subject's sex, age, marital status, place of residence and education.

The control group consisted of healthy subjects who declared no mental illness or mental health complaints in the interview. The choice of individuals was matched to the clinical group as far as sex and age were concerned. The same set of tests was used in the control group and the clinical group, with the exception of the GAF scale which was not applied to the control group.

All persons in the two groups gave their written consent to participation in the study, which was conducted as part of an MA seminar. This was not an experimental study; only well tried and tested methods and tools were used in its conduct, so it did not need to be submitted for the evaluation of the scientific research ethics committee.

The statistical analysis was carried out with the use of the SPSS 21 package and descriptive statistics were presented by means of arithmetic averages and standard deviations. We began our analysis with checking the nature of the distribution of variables. In the withdrawal (I) section of the Social Functioning Scale, in the clinical group, the analysis of kurtosis (3.44) and skewness $(-0.11)$ indicated that the distribution significantly varied from normal. Also the distribution of the variable subscale possible independence (VI) of the Social Functioning Scale significantly varied in both the clinical and the control groups. In the clinical group the skewness was -1.16 and kurtosis 4.43 and in the control group the skewness was -2.90 and kurtosis 8.26. Non-parametric tests were used for these variables: the Mann-Whitney Test and the Kruskal-Wallis Test. The parametric correlation $r$-Pearson's coefficient was used for scales II, III, IV, V, complying with the condition of normal distribution. Its counterpart, the non-parametric rho Spearman's correlation coefficient, was used for the scales deviating from normal (I, VI).

The significance level was adopted at $p \leq 0.05$ and the level of statistical tendency not exceeding $p=0.08$.

\section{RESULTS}

\section{Group characteristics}

Initially, the study involved 76 people, 38 in the control group and 38 patients in the clinical group. However, finally only 37 individuals ( 16 women and 21 men) were
- Skala Funkcjonowania Społecznego (GAF) - ocenia ogólne funkcjonowanie badanych w następujących trzech zakresach: psychopatologii, funkcjonowania społecznego i zawodowego. Skala składa się z dziesięciu przedziałów - od najniższego do najwyższego. Poziom 0 to skrajnie złe funkcjonowanie, 100 - funkcjonowanie bardzo dobre [20].

- Kwestionariusz Danych Społeczno-Demograficznych sporządzony na potrzeby badania, dotyczył: płci, wieku, stanu cywilnego, zamieszkania oraz wykształcenia.

W grupie kontrolnej znalazły się osoby zdrowe, które w wywiadzie nie deklarowały wystąpienia jakiejkolwiek choroby psychicznej i nie skarżyły się na jakiekolwiek zaburzenia psychiczne. Były to osoby dopasowane do grupy pacjentów pod względem wieku i płci. W grupie kontrolnej zastosowano podobny komplet materiałów jak w grupie klinicznej, a jedyna różnica polegała na braku skali GAF.

Wszystkie osoby badane obydwu grup wyraziły i podpisały zgodę na udział w badaniu. Badanie było wynikiem seminarium magisterskiego. Nie było to także badanie eksperymentalne oraz $\mathrm{w}$ jego realizacji używano tylko znanych i uznanych narzędzi badawczych. Z powyższych powodów uznano, że nie będzie ono poddane ocenie komisji etycznej do spraw badań naukowych.

Otrzymane wyniki poddano analizie statystycznej przy użyciu pakietu statystycznego SPSS 21 . Statystyki opisowe zostały przedstawione za pomocą wartości średnich arytmetycznych i odchyleń standardowych. Analizy rozpoczęto od sprawdzenia charakteru rozkładu zmiennych. W podskali „wychodzenie z izolacji” (I) Skali Funkcjonowania Społecznego, w grupie klinicznej analiza kurtozy $(3,44)$ oraz skośności $(-0,11)$ wskazuje, że rozkład odbiegał istotnie od rozkładu normalnego. W grupie klinicznej oraz kontrolnej od rozkładu normalnego istotnie odstawał również rozkład zmiennej podskali „samodzielność możliwa” (VI) w Skali Funkcjonowania Społecznego. W grupie klinicznej skośność wyniosła $-1,16$, a kurtoza 4,43, w kontrolnej zaś skośność wyniosła $-2,90$, a kurtoza 8,26 . Dla tych zmiennych wykorzystane zostały testy nieparametryczne: test Manna-Whitneya oraz test Kruskala-Wallisa. Spełniając warunek o rozkładzie normalnym - dla skal II, III, IV, V, użyto parametrycznego współczynnika korelacji $r$ Pearsona, zaś do skal o rozkładzie odbiegającym od normalnego (I, VI) użyto jego odpowiednika nieparametrycznego współczynnika korelacji rho Spearmana. Przyjęto poziom istotności $p \leq 0,05$ oraz poziom tendencji statystycznej nieprzekraczający $p=0,08$.

\section{WYNIKI}

\section{Charakterystyka badanej grupy}

W badaniu początkowo wzięło udział 76 osób - 38 z grupy kontrolnej i 38 z grupy klinicznej. W grupie kontrolnej analizom poddano jednak 37 osób - 16 kobiet 
Worrying in people with schizophrenia

Martwienie się osób chorujących na schizofrenię

Table 1. Marital status data. Percentages, frequency and differences between groups $(N=75)$

Tabela 1. Stan cywilny osób badanych. Wartości procentowe, frekwencyjne i różnice między grupami $(N=75)$

\begin{tabular}{|c|c|c|c|c|c|c|c|}
\hline $\begin{array}{l}\text { Group/ } \\
\text { Grupa }\end{array}$ & $\begin{array}{l}\text { Sex/ } \\
\text { Pleć }\end{array}$ & $\begin{array}{l}\text { Unmarried/ } \\
\text { Kawaler/panna }\end{array}$ & $\begin{array}{l}\text { Married/ } \\
\text { Małżeństwo }\end{array}$ & $\begin{array}{c}\text { Widow/er/ } \\
\text { Wdowiec/wdowa }\end{array}$ & $\begin{array}{l}\text { Divorced/ } \\
\text { Rozwód }\end{array}$ & $\chi^{2}(3.1)$ & $p$ \\
\hline \multirow{2}{*}{$\begin{array}{l}\text { Clinical/ } \\
\text { Kliniczna }\end{array}$} & $F / K$ & $15(93.8 \%)$ & $1(6.3 \%)$ & 0 & 0 & \multirow{4}{*}{15.256} & \multirow{4}{*}{0.002} \\
\hline & $\mathrm{M} / \mathrm{M}$ & 19 (86.4\%) & $2(9.1 \%)$ & 0 & 1 (4.5\%) & & \\
\hline \multirow{2}{*}{$\begin{array}{l}\text { Control/ } \\
\text { Kontrolna }\end{array}$} & $\mathrm{F} / \mathrm{K}$ & $4(25 \%)$ & $8(50 \%)$ & $2(12.5 \%)$ & $2(12.5 \%)$ & & \\
\hline & $\mathrm{M} / \mathrm{M}$ & $14(66.7 \%)$ & 7 (33.3\%) & 0 & 0 & & \\
\hline
\end{tabular}

Table 2. Live-in situation/family status. Percentages, frequency and differences between groups $(N=75)$ Tabela 2. Zamieszkanie osób badanych. Wartości procentowe, frekwencje i różnice między grupami $(N=75)$

\begin{tabular}{|c|c|c|c|c|c|c|c|}
\hline $\begin{array}{l}\text { Group/ } \\
\text { Grupa }\end{array}$ & $\begin{array}{l}\text { Sex/ } \\
\text { Płeć }\end{array}$ & $\begin{array}{l}\text { Family of origin/ } \\
\text { Rodzina pochodzenia }\end{array}$ & $\begin{array}{l}\text { New family/ } \\
\text { Rodzina założona }\end{array}$ & $\begin{array}{l}\text { Living with somebody else/ } \\
\text { Z kimś innym }\end{array}$ & $\begin{array}{l}\text { Living alone/ } \\
\text { Samotni }\end{array}$ & $\chi^{2}(3.1)$ & $p$ \\
\hline \multirow{2}{*}{$\begin{array}{l}\text { Clinical/ } \\
\text { Kliniczna }\end{array}$} & $F / K$ & $10(62.5 \%)$ & $1(6.3 \%)$ & $1(6.3 \%)$ & $4(25 \%)$ & \multirow{4}{*}{25.019} & \multirow{4}{*}{0.001} \\
\hline & $\mathrm{M} / \mathrm{M}$ & $15(68.2 \%)$ & $2(9.1 \%)$ & 0 & $5(22.7 \%)$ & & \\
\hline \multirow{2}{*}{$\begin{array}{l}\text { Control/ } \\
\text { Kontrolna }\end{array}$} & $F / K$ & $3(18.8 \%)$ & $11(68.8 \%)$ & $1(6.3 \%)$ & $1(6.3 \%)$ & & \\
\hline & $\mathrm{M} / \mathrm{M}$ & $4(19 \%)$ & 8 (38.1\%) & $4(19 \%)$ & 5 (23.8\%) & & \\
\hline
\end{tabular}

assessed in the control group as one man was excluded after scoring too low on the Worrying Assessment Questionnaire. The clinical group consisted of 16 women (42.1\%) and 22 men (57.9\%). In the group of women with schizophrenia the mean duration of illness was 12.44 years $(\mathrm{SD}=6.99)$ and in men's group it was 12.82 years $(\mathrm{SD}$ $=8.19$ ). The number of hospitalizations in the women's group was 6.44 on average $(S D=3.48)$ and in men's it was $7.32(\mathrm{SD}=4.56)$. In the clinical group the average age was 36.25 years old and in the control group it was 36 , so the two groups were similar as far as the subjects' age was concerned; most were in their mid-adulthood.

The two groups were analysed for their marital status as detailed in Table 1.

The results demonstrate that the groups under comparison differed as far as their marital status was concerned. The clinical group, as opposed to the control group, was dominated by single people.

The socio-demographic data was also analysed for information on our subjects' home circumstances, as detailed in Table 2.

The data presented in Table 2 demonstrates that the family status/live-in situation of people in the two groups is also different. In control group most people live in a family they have founded, whereas in the clinical group most people live in the family of origin. The percentage of men who live alone is similar in both groups.

As demonstrated in Table 3, in the clinical group people were on average educated to the secondary level, although women with schizophrenia were mostly educated to the MA level. Also in the control group women most were educated to the MA level whereas men were split between MA-level education and secondary education. i 21 mężczyzn. Decyzję o wykluczeniu jednego mężczyzny podjęto z powodu uzyskanego przez niego niskiego wyniku w Kwestionariuszu Oceny Martwienia się. Grupę kliniczną stanowiło 16 kobiet $(42,1 \%)$ oraz 22 mężczyzn $(57,9 \%)$. W grupie chorujących kobiet średnia liczba lat chorowania wyniosła 12,44 $(\mathrm{SD}=6,99)$, zaś u mężczyzn 12,82 (SD = 8,19). Liczba hospitalizacji w grupie kobiet wyniosła średnio 6,44 (SD = 3,48), zaś u mężczyzn 7,32 $(\mathrm{SD}=4,56)$. W grupie klinicznej średnia wieku wynosiła 36,25 roku, w grupie kontrolnej 36 , tak więc były to osoby w zbliżonym wieku i w okresie średniej dorosłości.

Badane grupy analizowano pod względem ich stanu cywilnego. Szczegóły przedstawiono w tabeli 1.

Zaprezentowane wyniki pokazują, że porównywane grupy różnią się pod względem stanu cywilnego. W grupie klinicznej dominują osoby samotne, przeciwnie aniżeli jest to obserwowane w grupie kontrolnej.

Uzyskane dane społeczno-demograficzne analizowano także pod względem informacji o tym, z kim badane osoby zamieszkują. Szczegóły przedstawiono w tabeli 2.

Przeprowadzone analizy pokazują, że grupy różnią się pod względem statusu rodzinnego. Najwięcej osób mieszkających z założoną przez siebie rodziną pochodzi z grupy kontrolnej, podczas gdy osoby z grupy klinicznej żyją przede wszystkim z rodziną pochodzenia. W obydwu grupach zbliżona liczba mężczyzn żyje samotnie.

Grupę osób chorujących na schizofrenię tworzyły głównie osoby z wykształceniem średnim (tab. 3). W grupie chorujących kobiet znaczną część stanowiły te z wykształceniem wyższym magisterskim. W grupie osób zdrowych kobiety w większości posiadały wykształcenie wyższe magisterskie, zaś w grupie mężczyzn tyle samo osób posiadało wykształcenie wyższe magisterskie, jak i wykształcenie średnie. 
Table 3. Education level. Percentages, frequency and differences between groups $(N=75)$

Tabela 3. Wykształcenie osób badanych. Wartości procentowe, frekwencje i różnice między grupami $(N=75)$

\begin{tabular}{|c|c|c|c|c|c|c|c|}
\hline $\begin{array}{l}\text { Group/ } \\
\text { Grupa }\end{array}$ & $\begin{array}{l}\text { Sex/ } \\
\text { Płeć }\end{array}$ & $\begin{array}{c}\text { Primary/ } \\
\text { Podstawowe }\end{array}$ & $\begin{array}{l}\text { Secondary/ } \\
\text { Średnie }\end{array}$ & $\begin{array}{c}\text { Higher (BA)/ } \\
\text { Wyższe licencjackie }\end{array}$ & $\begin{array}{c}\text { Higher (MA)/ } \\
\text { Wyższe magisterskie }\end{array}$ & $\chi^{2}(3.1)$ & $p$ \\
\hline \multirow{2}{*}{$\begin{array}{l}\text { Clinical/ } \\
\text { Kliniczna }\end{array}$} & $F / K$ & $2(12.5 \%)$ & $7(43.8 \%)$ & $1(6.3 \%)$ & $6(37.5 \%)$ & \multirow{4}{*}{12.96} & \multirow{4}{*}{0.005} \\
\hline & $\mathrm{M} / \mathrm{M}$ & $4(18.2 \%)$ & 12 (54.5\%) & $4(18.2 \%)$ & 2 (9.1\%) & & \\
\hline \multirow{2}{*}{$\begin{array}{l}\text { Control/ } \\
\text { Kontrolna }\end{array}$} & $F / K$ & 0 & $3(18.8 \%)$ & 0 & $13(81.3 \%)$ & & \\
\hline & $\mathrm{M} / \mathrm{M}$ & $1(4.8 \%)$ & 9 (42.9\%) & $2(9.5 \%)$ & $9(42.9 \%)$ & & \\
\hline
\end{tabular}

Table 4. Social functioning assessed with the use of the Social Functioning Scale (SFS) in the clinical and control groups. Mean values and differences between them $(N=75)$

Tabela 4. Funkcjonowanie społeczne mierzone Skalą Funkcjonowania Społecznego (SFS) w grupie klinicznej i kontrolnej. Średnie wartości i różnice między nimi $(N=75)$

\begin{tabular}{|l|c|c|c|c|c|c|c|c|}
\hline \multirow{2}{*}{$\begin{array}{l}\text { Social Functioning Scale/ } \\
\text { Skala Funkcjonowania Społecznego }\end{array}$} & \multicolumn{2}{|c|}{ Clinical Group/Grupa kliniczna } & \multicolumn{2}{|c|}{ Control Group/Grupa kontrolna } & \multicolumn{2}{|c|}{ Test } \\
\cline { 2 - 8 } & $\mathbf{N}$ & $\mathbf{M}$ & $\mathbf{S D}$ & $\mathbf{N}$ & $\mathbf{M}$ & SD & F (1.71) & $\mathbf{P}$ \\
\hline $\begin{array}{l}\text { Withdrawal (I)/ } \\
\text { Wychodzenie z izolacji (I) }\end{array}$ & 38 & 9.26 & 1.95 & 37 & 11.73 & 2.3 & 22.99 & 0.001 \\
\hline $\begin{array}{l}\text { Interpersonal functioning (II)/ } \\
\text { Komunikacja i więzi międzyludzkie (II) }\end{array}$ & 38 & 6.68 & 3.09 & 37 & 12.46 & 3.75 & 49.37 & 0.001 \\
\hline $\begin{array}{l}\text { Pro-social activities (III)/ } \\
\text { Kontakty społeczne (III) }\end{array}$ & 38 & 11.71 & 6.56 & 37 & 22.40 & 7.84 & 37.65 & 0.001 \\
\hline $\begin{array}{l}\text { Recreation (IV)/ } \\
\text { Rekreacja (IV) }\end{array}$ & 38 & 13.68 & 5.20 & 37 & 19.40 & 6.16 & 17.29 & 0.001 \\
\hline $\begin{array}{l}\text { Independent (c) (V)/ } \\
\text { Samodzielność realizowana (V) }\end{array}$ & 38 & 23.92 & 6.13 & 37 & 29.70 & 6.02 & 16.66 & 0.001 \\
\hline $\begin{array}{l}\text { Independence (p) (VI)/ } \\
\text { Samodzielność możliwa (VI) }\end{array}$ & 35.79 & 4.34 & 37 & 38.35 & 1.64 & 12.15 & 0.001 \\
\hline
\end{tabular}

$N$ - number/liczebność, M- mean/średnia, SD - standard deviation/odchylenie standardowe

\section{Social functioning}

In the clinical group, the mean score in the Social Functioning Scale was 101.05 (SD = 17.40) and in the control group the equivalent figure was 134.05 ( $\mathrm{SD}=20.18$ ). The scores from individual tests are presented in Table 4.

As demonstrated, people in the control group scored higher in the Social Functioning Scale than those in the clinical group. In fact, healthy people scored higher in all subscales than people with schizophrenia.

It should be noted that none of the people in the clinical group worked or studied, though they declared that they would want to work should the opportunity present itself. In the control group everybody was in employment.

The assessment with the GAF scale, carried out among the subjects in the clinical group, with its analysis in the context of psychopathology, was also an important part of our study. The results demonstrated that people with schizophrenia were functioning on the moderate level as far as the severity of social and professional difficulties was concerned. The differences between women and men are presented in Table 5.

\section{Funkcjonowanie społeczne}

W grupie klinicznej średni wynik w Skali Funkcjonowania Społecznego wyniósł 101,05 (SD = 17,40), zaś w grupie kontrolnej $134,05(S D=20,18)$. Wyniki z poszczególnych testów przedstawiono w tabeli 4.

Badani z grupy kontrolnej uzyskali wyższy wynik w Skali Funkcjonowania Społecznego niż badani z grupy osób chorujących na schizofrenię. W poszczególnych podtestach osoby zdrowe wypadały lepiej niż osoby chore.

Należy także odnotować, że osoby z grupy klinicznej nie były zatrudnione i nie uczyły się, oraz deklarowały chęć podjęcia pracy, gdy tylko nadarzy się ku temu sposobność. W grupie kontrolnej wszystkie osoby miały zatrudnienie.

Innym rodzajem pomiaru funkcjonowania osób w grupie klinicznej była ocena dokonana na podstawie skali GAF, gdzie ważnym czynnikiem była jego analiza w kontekście psychopatologii. Otrzymane wyniki wskazują, że osoby chorujące na schizofrenię znajdowały się na umiarkowanym poziomie funkcjonowania pod względem nasilenia objawów oraz trudności społecznych i zawodowych. Analiza dotyczyła także różnic pomiędzy kobietami i mężczyznami chorującymi na schizofrenię. Szczegóły przedstawiono w tabeli 5. 
Worrying in people with schizophrenia

Martwienie się osób chorujących na schizofrenię

Table 5. The measure of overall functioning of women and men in the clinical group. Mean values and the differences between them $(N=38)$

Tabela 5. Poziom ogólnego funkcjonowania kobiet i mężczyzn z grupy klinicznej. Wartości średnie i różnice między nimi $(N=38)$

\begin{tabular}{|l|c|c|c|c|}
\hline Sex/Płeć & N & M & SD & Statistics/Statystyka F (1,36) \\
\hline Women/Kobiety & 16 & 61 & 12 & \\
\cline { 1 - 4 } Men/Mężczyźni & 22 & 54 & 14.27 & \multirow{2}{*}{0.08} \\
\hline
\end{tabular}

$N$ - number/liczebność, M-mean/średnia, SD - standard deviation/odchylenie standardowe

Table 6. Tendency to worrying (PSWQ) in the clinical and control groups. Mean values and the differences between them $(N=75)$ Tabela 6. Skłonności do martwienia się (PSWQ) w grupie klinicznej i kontrolnej. Wartości średnie i różnice między nimi ( $N=75)$

\begin{tabular}{|c|c|c|c|c|c|c|c|c|}
\hline & \multicolumn{3}{|c|}{ Clinical group/Grupa kliniczna } & \multicolumn{3}{|c|}{ Control group/Grupa kontrolna } & \multicolumn{2}{|c|}{ Test } \\
\hline & $\mathbf{N}$ & M & SD & $\mathbf{N}$ & M & SD & $F(1.71)$ & $p$ \\
\hline $\begin{array}{l}\text { Intensity of worrying/ } \\
\text { Nasilenie martwienia się }\end{array}$ & 38 & 54.89 & 14 & 37 & 49.19 & 14.12 & 3.253 & 0.076 \\
\hline
\end{tabular}

$N$ - number/liczebność, $M$ - mean/średnia, SD - standard deviation/odchylenie standardowe

Table 7. Co-efficients of correlation between severity of worrying and various subscales of social functioning (SFS) in the clinical and control groups $(N=75)$

Tabela 7. Współczynniki korelacji pomiędzy nasileniem martwienia się a poszczególnymi skalami funkcjonowania społecznego (SFS) w grupie klinicznej i kontrolnej $(N=75)$

\begin{tabular}{|c|c|c|}
\hline Social functioning scale/Skale funkcjonowania społecznego & Clinical group/Grupa kliniczna & Control group/Grupa kontrolna \\
\hline Withdrawal (I)/Wychodzenie z izolacji (I) & rho $=0.036 ; p=0.831$ & rho $=-0.211 ; p=0.209$ \\
\hline Interpersonal functioning (II)/Komunikacja i więzi międzyludzkie (II) & $r=-0.486 ; p=0.02$ & $r=0.028 ; p=0.867$ \\
\hline Pro-social activities (III)/Kontakty społeczne (III) & $r=0.225 ; p=0.174$ & $r=-0.082 ; p=0.631$ \\
\hline Recreation (IV)/Rekreacja (IV) & $r=-0.289 ; p=0.078$ & $r=0.083 ; p=0.623$ \\
\hline Independent (c) (V)/Samodzielność realizowana (V) & $r=-0.156 ; p=0.349$ & $r=0.263 ; p=0.116$ \\
\hline Independence (p) (VI)/ Samodzielność możliwa (VI) & rho $=-0.048 ; p=0.773$ & rho $=-0.337 ; p=0.041$ \\
\hline
\end{tabular}

Our results show that overall women with schizophrenia function better than men and that differences between the mean values are at the level of statistical tendency.

\section{Worrying}

In the model of one-way analysis of variance, it was observed that the difference in the intensity of worrying between the two groups occurred at the level of statistical tendency (Table 6). It cannot be ruled out therefore that there are differences in the intensity of worrying between people with schizophrenia and healthy subjects.

Further analyses showed no differences in the level of worrying between women and men in our groups $\mathrm{F}(1.71)=0.016 ; p=0.899$. Notably, however, both groups under analysis represented a moderate level of worrying (44-62 points).
Otrzymane wyniki pokazują, że kobiety chore na schizofrenię funkcjonują lepiej aniżeli mężczyźni. Odnotowane różnice pomiędzy średnimi są na poziomie tendencji statystycznej.

\section{Martwienie się}

W modelu analizy wariancji jednej zmiennej zaobserwowano, że różnica w natężeniu martwienia się pomiędzy grupami występuje na poziomie tendencji statystycznej (tab. 6). W związku z tym nie można wykluczyć, że występują różnice $\mathrm{w}$ natężeniu martwienia się między osobami chorującymi na schizofrenię a osobami zdrowymi.

Dalsze analizy nie wykazały różnic w poziomie martwienia się między kobietami i mężczyznami w poszczególnych grupach $\mathrm{F}(1,71)=0,016 ; p=0,899$. Należy jednak odnotować, że obydwie porównywane grupy prezentowały średni poziom martwienia się (44-62 punkty). 


\section{Worrying and social functioning}

Table 7 presents covariance indicators between worrying and other areas of social functioning. Our analysis showed a moderately strong negative correlation between the tendency to worry, communication and interpersonal relationships of people suffering from schizophrenia $(r=-0.486, p=0.02)$. Negative correlation at the level of statistical tendency was also observed between the tendency to worry and satisfying ways of spending leisure time (recreations, hobbies) in the clinical group $(r=-0.289, p=0.078)$.

A statistically significant covariance was observed in the control group as far as the level of worrying and possible independence were concerned. The correlation was negative and rather weak ( rho $=-0.337$; $p=0.041)$.

Further analyses of the value of correlation coefficients between the tendency to worry and other dimensions of social functioning failed to reveal any statistically significant relationships.

\section{DISCUSSION}

The objective of this study was to analyse the prevalence of worrying, and relationships that may exist between worrying and other areas of the social functioning of people with schizophrenia when compared to healthy subjects.

The literature on the subject suggests that the intensity of worrying in people with schizophrenia is similar to that observed in patients with generalized anxiety $[21,22]$. In their daily lives people with schizophrenia experience more anxiety and fear than healthy people [23]. Freeman's research suggests that a higher degree of worrying, bordering on the chronic i.e. above 63 points in PSWQ, may stimulate the appearance of paranoid symptoms in people with schizophrenia [19]. The elevated level of symptoms of anxiety in patients is often associated not only with paranoid thoughts but also with persecutory delusions [24]. Anxiety is sometimes associated with experiencing worrying, yet research demonstrates that worrying can also occur without the accompanying anxiety [25].

In the clinical group under analysis the intensity of psychotic symptoms, including anxiety, was such that it would make the patients' daily functioning and participation in intensive rehabilitation and therapeutic activities possible. At the core of these activities was training in social, cognitive skills and social cognition which required that the severity of psychotic symptoms had been low. At the same time, our patients were very experienced at being ill as most of them were middle-aged, ill for over ten years, with many hospitalizations behind them. They were also in the stable phase of their illness and consistent

\section{Marłwienie się a funkcjonowanie społeczne}

W tabeli 7 przedstawiono wskaźniki współzmienności pomiędzy martwieniem się a poszczególnymi obszarami funkcjonowania społecznego. Analiza wykazała umiarkowanie silną ujemną korelację pomiędzy skłonnościami do martwienia się a komunikacją oraz więzią międzyludzką, jaką tworzą osoby chorujące na schizofrenię $(r=-0,486 ; p=0,02)$. Otrzymano również ujemną korelację na poziomie tendencji statystycznej między skłonnościami do martwienia się a satysfakcjonującym spędzaniem czasu wolnego (rekreacja, hobby) w grupie klinicznej $(r=-0,289 ; p=0,078)$.

Istotną statystycznie współzmienność stwierdzono również w grupie kontrolnej - dotyczyła ona poziomu martwienia się i samodzielności możliwej. Uzyskana korelacja była ujemna i na niskim poziomie ( $\mathrm{rho}=-0,337 ; p=0,041$ ).

Pozostałe analizy wartości współczynników korelacji pomiędzy tendencją do martwienia się i innymi wymiarami funkcjonowania społecznego nie wykazały związków istotnych statystycznie.

\section{DYSKUSJA}

Celem prezentowanego badania była analiza rozmiaru i związków, jakie może mieć proces martwienia się w różnych obszarach funkcjonowania społecznego osób chorych na schizofrenię, w porównaniu z osobami zdrowymi.

W doniesieniach badawczych odnotowuje się, że nasilenie martwienia się u osób chorych na schizofrenię jest na podobnym poziomie jak wśród pacjentów z lękiem uogólnionym [21, 22]. Osoby chore na schizofrenię doświadczają w swoim codziennym życiu więcej niepokoju i lęku aniżeli osoby zdrowe [23]. Badania Freeman sugerują, że nasilony poziom martwienia się powyżej 63 punktów (PSWQ), graniczący z zamartwianiem się, może stymulować pojawienie się objawów paranoicznych u osób chorych na schizofrenię [19]. Podwyższony poziom objawów lękowych u pacjentów często jest związany nie tylko z myślami paranoicznymi, ale także $\mathrm{z}$ urojeniami prześladowczymi [24]. Lęk bywa łączony z przeżywaniem martwienia się, jednak badania wykazują, że martwienie się może także występować samodzielnie, bez towarzyszącego mu lęku [25].

W analizowanej grupie klinicznej nasilenie objawów psychotycznych, w tym lękowych, znajdowało się na poziomie umożliwiającym codzienne funkcjonowanie oraz udział w intensywnych zajęciach rehabilitacyjno-terapeutycznych. Podstawę tych zajęć stanowią treningi: umiejętności społecznych, poznawcze i społecznego poznania, udział w których wymaga niskiego poziomu nasilenia objawów psychotycznych. Jednocześnie badani stanowili grupę, która miała bardzo bogate doświadczenia związane z chorowaniem. Były to osoby $\mathrm{w}$ średnim wieku, kilkanaście lat chorujące i mające za sobą wiele hospitalizacji. Były to 
pharmacological treatment but did not take any medication that might have affected the intensity of their worrying.

Studies using magnetic resonance showed that the drug that reduced the prefrontal cortex activity when exposed to stimuli that cause worry - citalopram - was not used by any of the patients in the group under analysis [26]. Other studies, however, highlighted the fact that a higher tendency to worry might be linked to being female [9]. In the research presented in this paper, the number of women and their demographic characteristics were controlled so that the two groups under comparison were similar to the greatest extent possible.

None of the patients participating in the study were employed at the time; they declared difficulties with finding a job and holding on to it in spite of having appropriate qualifications. At the same time, all our subjects from the clinical group had a disability certificate and received social benefits. They were mostly single with a level of functioning below what is considered satisfactory $($ GAF $<80)$. People with schizophrenia differed significantly from those in the control group when it came to their independence and social functioning in all ranges under analysis.

The results obtained indicate that patients with schizophrenia constitute a group with a higher severity of worrying when compared to the control group, yet the differences are only at the level of statistical tendency. In both groups the results of worry-related tests were similar, with scores on the average level (44-62 points) [19]. It is notable that these outcomes are different from those reported by other researchers who have emphasized the finding that people with schizophrenia tended to experience higher degrees of worry than healthy people $[19,22]$. However, it should also be noted that our subjects were older than the people in those studies by almost 10 years; they had also been ill for longer and hospitalized more often. These patients attended a daily rehabilitation programme, spending most of their time in their social environment. The setting in which they lived provided various mental healthcare, nursing and rehabilitation programmes which often replaced nonexistent family support systems. It can be assumed that with age, once the hope of a full recovery among these patients had diminished, that they might have come to accept their situation and their tendency to worry might have subsided. Perhaps, paradoxically, people that have been ill for a longer time worry less, so a drop in worrying might be age-related, as also proposed by other researchers [27].

In the clinical group, we observed a significantly negative and relatively strong correlation between the severity of worrying and the skill of communicating with others as well as with establishing relationships. At the same time, a statistical tendency was noted także osoby w stabilnej fazie choroby i sytuacji farmakologicznej oraz niezażywające leków mogących mieć wpływ na intensywność martwienia się. Badania $\mathrm{z}$ wykorzystaniem funkcjonalnego rezonansu magnetycznego wykazują, że lekiem mającym wpływ na zmniejszenie aktywności obszarów kory przedczołowej, przy ekspozycji na bodźce wywołujące martwienie się, jest citalopram - lek niestosowany w analizowanej grupie pacjentów [26]. Istnieją badania podkreślające, że sam proces martwienia się może być związany z płcią żeńską [9]. W prezentowanym badaniu kontrolowano liczbę kobiet oraz opisujące je właściwości demograficzne, tak aby porównywane grupy były podobne do siebie w jak największym zakresie.

Pacjenci uczestniczący w badaniu nie mieli aktualnie pracy, deklarowali trudności z jej podjęciem i utrzymaniem, często pomimo posiadanego wykształcenia. Jednocześnie wszystkie osoby z grupy klinicznej posiadały orzeczenie o niepełnosprawności i pobierały rentę lub zasiłek oraz były to osoby w większości samotne i niebędące w związkach. Ponadto były to osoby, których poziom funkcjonowania znajdował się poniżej tego uznawanego za wystarczająco dobry $(\mathrm{GAF}<80)$. Osoby chore na schizofrenię istotnie różniły się pod względem samodzielności i funkcjonowania społecznego od osób z grupy kontrolnej, we wszystkich analizowanych zakresach.

Otrzymane w prezentowanym badaniu wyniki wskazują, że pacjenci stanowią grupę o większym nasileniu procesu martwienia się w porównaniu z grupą kontrolną osób zdrowych, jednak uzyskane różnice występują jedynie na poziomie tendencji statystycznej. W porównywanych grupach wyniki martwienia się były zbliżone i na średnim poziomie (44-62 punkty) [19]. Jest to wynik odmienny od doniesień innych autorów, którzy podkreślają, że osoby chore na schizofrenię mają tendencję do wyższego poziomu martwienia się niż osoby zdrowe $[19,22]$. Należy jednak odnotować, że osoby z prezentowanego badania były zdecydowanie starsze (prawie o 10 lat), dłużej chorowały i częściej były hospitalizowane. Były to osoby przebywające $\mathrm{w}$ trybie dziennym rehabilitacji, spędzające większość czasu poza oddziałem w swoim środowisku społecznym. Środowisko, w jakim przebywają badani z grupy klinicznej, jest bogate w różnorodne systemy oddziaływań opiekuńczo-rehabilitacyjnych. Systemy te sprawnie zastępują naturalne, często już nieistniejące systemy wsparcia rodzinnego. Można przypuszczać, że gdy w miarę upływu lat ubywa nadziei na wyzdrowienie, może pojawić się akceptacja swojej sytuacji życiowej i tym samym dochodzi do normalizacji skłonności do martwienia się. Być może osoby dłużej chorujące zaczynają się mniej martwić i proces ten może się wiązać $\mathrm{z}$ wiekiem, tak jak jest to obserwowane w innych badaniach [27].

$\mathrm{W}$ grupie klinicznej odnotowano istotną, ujemną i umiarkowanie silną korelację pomiędzy nasileniem martwienia się i poziomem umiejętności komunikowania się $\mathrm{z}$ innymi oraz realizowanymi związkami. Jednocześnie odnotowano pewną tendencję statystyczną, w ujemnej i ni- 
in a negative and low correlation between worrying and the willingness to take advantage of satisfying leisure activities. This is consistent with other research which demonstrated that a tendency to worry had a number of negative consequences for an individual's life. People who worry experience a low tolerance of uncertainty, higher feelings of disability and lower satisfaction with life [28]. Various studies show that people who cope well with life worry little, although the experience itself is not entirely excluded [29]. Worrying about trivial things may bring about good solutions to important problems. This kind of worrying is often linked to attracting attention away from the real problem, hence it deters an individual from taking action and gives them time to make a good decision [30]. In that case worrying itself may be treated as an essential part of coping with problems in emotional and task-solving areas, yet the manner in which it is used is a key ingredient [27]. People with schizophrenia have no effective social skills that would help them externalize their worries and get help from others [29]. This can cause difficulties, as research shows that natural social support networks are exceptionally small and inefficient in case of people with schizophrenia [30]. Yet as it turned out, the patients in our clinical group had access to particularly effective institutionalized community support systems, such as patients' clubs, support groups, home treatment teams, protected housing and aid centres. These institutions take care of most people with schizophrenia, particularly those with many social functioning deficits, providing a possibility for patients to have many of their needs met even though receiving help in this way might have a stigmatizing effect and in a way amplify their worrying.

\section{CONCLUSIONS}

The results of the study do not unequivocally confirm that people with schizophrenia are more prone to worrying than the healthy subject. In fact a significant and inversely proportional covariance was observed between the level of worrying and some aspects of social functioning. These results may have important practical implications for psychiatric rehabilitation and also for the community-based interventions available to people with schizophrenia.

These results and their interpretation are not without their limitations, hence they should not be generalized to the entire population of patients with schizophrenia. Our research sample was not representative and was taken from a specific group of patients who lived in a social environment in the Warsaw district of Mokotów, which is very well provided with healthcare and rehabilitation facilities. The correlative nature of the research makes it impossible to draw unequivo- skiej korelacji pomiędzy martwieniem się a chęcią korzystania $\mathrm{z}$ zajęć rekreacyjnych, przynoszących zadowolenie i zagospodarowujących wolny czas. Jest to zgodne z innymi badaniami pokazującymi, że osoby ze skłonnością do martwienia się ponoszą szereg negatywnych konsekwencji w życiu. Osoby takie mają niską tolerancję niepewności, większe poczucie niepełnosprawności i słabsze poczucie zadowolenia z życia [28]. Badania pokazują, że zaradności życiowej towarzyszy niski poziom martwienia się, jednak nie wyklucza tego procesu zupełnie [29]. Martwienie się mało ważnymi sprawami może przynosić korzystne rozwiązania spraw ważnych. Takie martwienie się często ma na celu odwrócenie uwagi od realnego problemu, odracza $\mathrm{w}$ czasie podjęcie działania i tym samym daje czas na podjęcie decyzji [30]. Tak więc samo martwienie się może być traktowane jako istotny sposób radzenia sobie z problemami w warstwie emocjonalnej i zadaniowej, jednak kluczowy jest sposób jego wykorzystywania [27]. Osoby chore na schizofrenię nie mają skutecznych umiejętności społecznych umożliwiających wykorzystanie uzewnętrznianego martwienia się w uzyskiwaniu pomocy od innych [29]. Może to być trudne, bo jak pokazują badania, naturalne sieci społecznego wsparcia osób chorych na schizofrenię są wyjątkowo ubogie i niewydolne, co tym bardziej ogranicza możliwości czerpania $z$ nich pomocy [30]. Jednak w środowisku osób z grupy klinicznej sprawnie i bardzo efektywnie działają zinstytucjonalizowane środowiskowe systemy wsparcia (kluby pacjentów, środowiskowe domy wsparcia, zespoły leczenia domowego, mieszkania chronione, ośrodki pomocy). I to dzięki nim opieką jest objęta większość osób chorych na schizofrenię, szczególnie tych $\mathrm{z}$ wieloma deficytami funkcjonowania społecznego. Dzięki takiej organizacji istnieje możliwość realizowania wielu potrzeb pacjentów, co jednak być może działa także stygmatyzująco i sprzyja przeżywaniu martwienia się.

\section{WNIOSKI}

Na podstawie uzyskanych wyników nie można jednoznacznie stwierdzić, że osoby chore na schizofrenię martwią się bardziej aniżeli osoby zdrowe. Odnotowano jednak istotną i odwrotnie proporcjonalną współzmienność występującą pomiędzy poziomem martwienia się a niektórymi aspektami funkcjonowania społecznego. Uzyskane wyniki mogą stanowić ważne implikacje praktyczne dla rehabilitacji psychiatrycznej oraz oddziaływan środowiskowych realizowanych w grupie osób chorych na schizofrenię.

Interpretacja uzyskanych wyników nastręcza pewnych trudności. Nie należy ich uogólniać na całą populację osób chorych na schizofrenię, gdyż próba badawcza nie była reprezentatywna i pobrana została ze specyficznej grupy pacjentów, żyjących w bardzo różnorodnym i bogatym w oddziaływania opiekuńczo-rehabilitacyjne środowisku społecznym Warszawy w dzielnicy Mokotów. Korelacyjny charakter badań uniemożliwia jednoznaczne 
cal conclusions about the causal relationship between social functioning and the severity of the tendency to worry. wyciąganie wniosków o przyczynowym kierunku zależności pomiędzy funkcjonowaniem społecznym a nasileniem skłonności do martwienia się.

\section{Conflict of interest/Konflikt interesu}

Absent./Nie występuje.

\section{Financial support/Finansowanie}

Absent./Nie występuje.

\section{References/Piśmiennicłwo}

1. Eysenck M, Calvo MG. Anxiety and performance: The processing efficiency theory. Cogn Emotion 1992; 6: 409-434.

2. Hofmann SG. The worried mind: autonomic and prefrontal activation during worrying. Emotion 2005; 5: 464-475.

3. Krain A, Hefton S, Pine D, Ernst M, Castellanos F, Klein R, Milham MP. An FMRI examination of developmental differences in the neural correlates of uncertainty and decision-making. Journal Child Psychology and Psychiatry 2006; 47: 1023-1030.

4. Davey GCL. Worrying, social-problem solving abilities, and problem-solving confidence. Behav Res Ther 1994; 32: $327-330$.

5. Borkovec TD, Ray WJ, Stöber JS. Worry: Cognitive Phenomenon Intiomately Linked to Affective, Psychological, and Interpersonal Behavioral Processes. Cognitive Therapy and Research 1998; 22(6): 561-576.

6. Borkovec TD, Roemer L. Perceived functions of worry among generalized anxiety disorder subjects: Distraction from more emotionally distressing topics? Journal of Behavior Therapy and Experimental Psychiatry 1995; 26(1): 25-30.

7. Belzer KD, D'Zurilla TJ, Maydeu-Olivares A. Social problem solving and trait anxieties predictor of worry in a college student population. Personality and Individual Differences 2002; 30: 573-585.

8. Davey GCL, Levy S. Catastrophic Worrying: Personal Inadequacy and Perseverative Style as Features of the Catastrophizing Process. Journal of Abnormal Psychology 1998; 107(4): 576-586.

9. Janowski K, Solarz A. Skłonność do martwienia się, przekonania o martwieniu się a osobowość - analiza wzajemnych zależności i różnic płciowych. Postępy Psychiatrii i Neurologii 2013; 22(2): 103-112.

10. Starcevic V. Pathological worry in major depression: a preliminary report. Behav Res Ther 1995; 33: 55-56.

11. Omvik S, Pallesen S, Bjorvatn B, Thayer J, Hilde-Nordhus I. Night-time thoughts in high and low worriers: Reaction to caffeine-induced sleeplessness. Behav Res Ther 2007; 45: 715-727.

12. Wells A. Relationships between worry, obsessive-compulsive symptoms and meta-cognitive beliefs. Behav Res Ther 1998; 36: 899-913.

13. Sassaroli S, Bertelli S, Decoppi M, Crosina M, Milos G, Ruggiero GM. Worry and eating disorders: A psychopathological association. Eat Behav 2005; 6: 301-307.

14. Hopko DR, Bourland SL, Stanley MA, Beck JG, Novy DM, Averill PM, Swann AC. Generalized anxiety disorder in older adults: Examining the relations between clinician severity ratings and patient self-report measures. Depress Anxiety 2000; 12: 217-225.

15. Załuska M. Skala Funkcjonowania Społecznego (SFS) Birchwooda jako narzędzie oceny funkcjonowania chorych na schizofrenię. Post Psychiatr Neurol 1997; 6: 237-251.

16. Janowski K. Kwestionariusz Oceny Martwienia się, polska adaptacja PSWQ. Katedra Psychologii Klinicznej. Lublin: KUL; 2007.

17. Strober J, Bittencourt J. Weekly Assessment of Worry: An adaptation of the Penn State Worry Questionnaire for monitoring changes during treatment. Behaviour Research and Therapy 1998; 36(6): 645-656.

18. Castillo C, Macrini L, Cheniaux E, Fernandez J. Psychometric properties and latent structure of the Portuguese version of PSWQ. The Spanish Journal of Psychology 2010; 13(1): 431-443.

19. Freeman D, Dunn G, Startup H, Pugh K, Cordwell J, Mander H, Černis E, Wingham G, Shirvell K, Kingdon D. Effects of cognitive behaviour therapy for worry on persecutory delusions in patients with psychosis (WIT): a parallel, single-blind, randomised controlled trial with a mediation analysis. Lancet Psychiatry 2015 Apr; 2(4): 305-313. doi: 10.1016/S2215-0366(15)00039-5. Epub 2015 Mar 31.

20. Wciórka J, Muskat K, Matałowski P. Ocena przydatności skal funkcjonowania społecznego z systemu DSM-IV (GAF, SOFAS, GARF). Post Psychiatr Neurol 1997; 6(3): 253-268.

21. Morrison AP, Wells A. Relationships between worry, psychotic experiences and emotional distress in patients with schizophrenia spectrum diagnoses and comparisons with anxious and non-patient groups. Behv Res Ther 2007; 45(7): 1593-1600. 
22. Zajenkowski M, Styła R, Jędrasik-Styła M. Stres związany z wykonywaniem zadania a kontrola poznawcza u osób chorujących na schizofrenię. Psychiatr Pol 2015: 49(2): 337-347.

23. Tremeau F. A review of emotion deficit in schizophrenia. Dialogues Clin Neurosci 2006; 8(1): 58-68.

24. Freeman D, Stahl D, McManus S, Meltzer H, Brugha T, Wiles N. Insomnia, worry, anxiety and depression as predictors of the occurrence and persistence of paranoid thinking. Soc Psychiatry and Psychiatr Epidemiol 2012; 47(8): 1195-1203.

25. Levy S, Guttman L. Worry, fear, and concern differentiated. Issues Mental Health Nurs 1985; 7(1-4): 251-264.

26. Hoehn-Saric R. Effects of citalopram on worry and brain activation in patients with generalized anxiety disorder. Psychiatry Res 2004; 131: 11-21.

27. Graham C. Worry and anxiety in old age. Aging \& Mental Health 2003; 7(5): 323-325.

28. Kelly KE. The relationship between wiry and creative personality. Couns Clin Psychology J 2005; 2: 75-80.

29. Pattison M, Pattison M. Analysis of schizophrenia Psychosocial Network. Schizophrenia Bull 1981; 7(1): 135-143.

30. Bronowski P, Sawicka M, Kluczyńska S. Charakterystyka populacji objętej środowiskowym systemem rehabilitacji i wsparcia społecznego. Psychiatria Polska 2009; 4: 421-434. 